\title{
Effect of Self-Learning Guidelines on Quality of Life and Self -Care Reported Practice of Adolescents with Sickle Cell Anemia
}

\section{Nora Mahdy Fouda ${ }^{1}$, Randa Mohamed Adly ${ }^{2}$, Faten Shafik Mahmoud ${ }^{3}$ and Rawia Abd El- Ghany Mohamed ${ }^{4}$}

(1) Technical Nursing Institute, Al-Azhar University, (2) Professor of Pediatric Nursing, Faculty of Nursing, Ain Shams University,(3) Professor of Pediatric Nursing and (4) Lecturer of Pediatric Nursing, Faculty of Nursing, Benha University.

\section{Abstract}

Background: Sickle Cell Anemia (SCA) is a chronic hematologic disease associated with many physical, psychological, and social problems that can affect on quality of life. Self-learning guidelines has a great effect in improving quality of life and health status of adolescent with Sickle Cell Anemia. Aim of the study was to evaluate the effect of self-learning guidelines on quality of life and self-reported practice of adolescents with sickle cell anemia. Design: A quasi-experimental study. Settings: Inpatient and outpatient of pediatric hematology departments at Benha University and Benha Specialized Pediatric Hospitals. Study subjects: A purposive sample of 50 adolescents diagnosed with sickle cell anemia in the previously mentioned settings was included in the study throughout a period of six months. Data collection tools: A Structured interviewing questionnaire sheet, self-care reported practices and pediatric quality of life scale. Results: There was a statistical significant difference between total knowledge and total self-reported practices of the studied adolescents regarding to sickle cell anemia post and follow up self-learning guidelines as compared to pre self-learning guidelines implementation. There was a statistical significant difference between the total score of quality of life for the studied adolescents regarding to sickle cell anemia at post and follow up compared to pre selflearning guidelines implementation. Conclusion: Self-learning guidelines implementation was effective in improving the quality of life of adolescents with sickle cell anemia through improving their knowledge and self-care reported practices. Recommendations: In service training program for adolescents with the sickle cell anemia to enhance their quality of life.Conducting premarital screening programs for raising awareness of children and adolescents regarding the nature hereditary of SCA\& associated complication.

\section{Key words: Sickle cell anemia, Adolescents, Self-learning Guidelines, Quality of life, Self -Care} Reported Practice

\section{Introduction}

Sickle Cell Anemia (SCA) is a recessive single-gene inherited disorder causing significant morbidity and mortality. The main characteristics of sickle cell anemia are severe anemia that might require blood transfusion, repeated chest infections, episodes of pain, leg ulcers, pulmonary hypertension, splenic infarction, repeated strokes, necrosis of joints, and renal failure. Adolescents suffering from Sickle cell anemic usually require repeated hospitalization due to the associated complications (Downes, et al., 2019).Sickle Cell Anemia (SCA) is often associated with 
major complications in the long term, which may lead to a poor quality of life. The use of prophylactic antibiotics, such as penicillin, vaccines, and treatments reduce the severity of disease such as hydroxyurea have increased the average life span of these adolescents (Jain, et al., 2018). The concept of Health-Related QoL (HR-QoL) is defined as the individual's own subjective perception of aspects of life directly related to the state of health. Therefore, this concept represents the satisfaction and wellbeing of an individual as concerns the physical, psychological, social, economic, and spiritual domains of his/her state of health a combination of the state of health and the affective response to it (Lim, et al., 2019). Self-learning guidelines are the purposeful performance of specific learned tasks, skills, activities, and behaviors to manage the medical, psychosocial, and life impact of SCA. However, providing advice to adolescents on certain lifestyle factors, such as avoiding exposed to cold weather, dehydration, rigorous exercise and follow up health instructions is helpful in reducing crisis and complications (Lori, et al., 2019). Self-learning guidelines seem to be essential to improve quality of life and health status of adolescents with sickle cell anemia to achieve an acceptable level of quality of life. Moreover, the adolescents with SCA need a comprehensive and organized care, including medical and non-medical services as well as self-learning strategies. The acquisition or modification of effective coping strategies can lead to a reduction in symptoms, promote selfmanagement behaviors and health outcomes and achieve a better quality of life (Druye, et al., 2018)

\section{Signficance of the study:}

Sickle cell anemia is a major genetic disease that occurs more often among children from parts of the world where malaria is or was common. Each year over 300,000 babies with severe forms of these diseases are born worldwide, the majority in low and middleincome countries. It is estimated of 250,000 children have sickle cell anemia worldwide and $75 \%-85 \%$ of the affected children are in Africa, where mortality rates for those range from $50 \%$ to $80 \%$ due to the severity of disease's complication (Stephen, et al., 2018).

Sickle cell anemia is a chronic autoimmune disease that can involve any organ system with a wide range of disease manifestations, and can lead to significant morbidity and even mortality. Recent studies showed that positive progress for adolescents whom participants in self-learning guidelines courses as it results in decreased reports of pain, increased functional abilities and reduce numbers of hospitalization and physician visits.

Adolescents with sickle cell anemia suffering from many physical, psychological, and social problems that can affect their quality of life. To deal with this chronic condition, manage their disease, and prevent complications associated with the disease. Adolescents must learn skills and behaviors. Therefore, the aim of this study was to determine the effectiveness of self-learning guidelines on quality of life and self-care reported practice in these adolescents.

\section{Aim of the study}

This study aimed to evaluate the effect of selflearning guidelines on quality of life and self-care reported practice of adolescents with sickle cell anemia, through the following objectives:

1. Assess the quality of life and self-care reported practice of adolescents with sickle cell anemia. 


\section{Effect of Self-Learning Guidelines on Quality of Life and Self -Care Reported Practice of Adolescents with Sickle Cell Anemia}

2. Design and implement self-learning guidelines for the quality of life and self-care reported practice of adolescents with sickle cell anemia.

3. Evaluate the effect of self-learning guidelines on quality of life and self-care reported practice of adolescents with sickle cell anemia.

\section{Research Hypothesis:}

Quality of life and self-care reported practice of adolescents with sickle cell anemia will be improved after the implementation of selflearning guidelines.

\section{Subjects and Methods}

\section{Research design:}

A quasi-experimental design was utilized to conduct this study.

\section{Settings:}

The current study was conducted at the inpatient and outpatient of pediatric hematology departments at Benha University and Benha Specialized Pediatric Hospitals. The inpatient hematology department at Benha University present in the fourth floor at medicine building and consisted of two rooms each room contains six beds. The outpatient clinic present at first floor and consisted of one room with one bed.

In addition, the inpatient hematology department at Benha Specialized Pediatric Hospital was in the fourth floor in building (A) and consisted of two rooms each room contains four beds. The outpatient clinic present at first floor and consisted of one room with one bed.

\section{Subjects:}

A purposive sample of 50 adolescents diagnosed with sickle cell anemia in the previously mentioned settings were included in the study throughout a period of six months of data collection from the beginning of June up to the end of November 2019.

\section{Inclusion criteria:}

- Children from 12-18 years old.

- Fully conscious, oriented and able to follow instruction.

- Free from any other acute or chronic illnesses, handicapping conditions, and cognitive problems.

\section{Tools of Data Collection:}

Data was collected through using the following tools:

\section{Tool (I): A Structured Interviewing Questionnaire}

It was developed by the researcher in an Arabic language after reviewing the related literature. It was consists of two parts as the following:

Part (1): Personal characteristics, family history and medical history of the adolescents suffering from sickle cell anemia such as:

Data about the personal characteristic of the adolescents with sickle cell anemia such as age, gender, level of education, ranking of the child, residence and number of family member.

Data about the adolescents' family history such as consanguinity relationship between parents, the degree of this relation, any hereditary diseases in the family, another hematological diseases and presence of another person have sickle cell in the family.

Past and medical history of the adolescents such as the onset of the disease, receiving blood transfusion, frequency of receiving blood transfusion per weeks, complications from blood transfusion and number of hospitalization due to pain crisis during the last six months.

Part (2): Adolescents' knowledge about sickle cell anemia to assess; 
1-Adolescents' knowledge about blood and its components such as components of the blood, the place for the manufacture of the blood and its products, function of red blood cell (3 questions).

\section{2- Adolescents' Knowledge about sickle} cell anemia as definition, causes, predisposing factor of pain crisis, manifestations, complications, prevention of complication, diagnosis, prevention, treatment of sickle cell anemia, the appropriate precautions for dealing with sickle cell anemia and pain attack management (11 questions).

The total scoring system of adolescents' knowledge:

Three levels of scoring for each question was be as the following:

- Correct and complete answer was scored (2) grades.

- Correct and incomplete answer was scored (1) grade.

- Incorrect answer or don't know was scored (0).

So, the total score of 14 questions were 28 grades $(100 \%)$.

The total scoring system of adolescents' knowledge was calculated and classified in three levels as: For $75-100 \%$ was considered good level of knowledge 21-28 grades, for 60$<75 \%$ was considered average level of knowledge 17- $\langle r$ l grades and for less than $60 \%$ was considered poor level of knowledge $<17$ grades.

\section{Tool (II): Self-Care Reported Practices:}

This tool was developed by Hilker et al. (2006); it was adapted by the researcher to measure sickle cell anemia self-care reported practices. The tool was translated in simple
Arabic language and included, self-reported practices about the prescribed medications (8 items), sanitation (6 items), sleep (6 items), pain management (12 items), nutrition (5 items) and follow up (7 items). So the total items were (44 items).

\section{Scoring system for Self-Care Reported Practices:}

The adolescents' response for each statement was ranged from 1 (never), 2 (sometimes), 3(always). The total scoring system of adolescents' self-care reported practices was calculated and classified in two levels as: For $80 \% \&$ above was considered satisfactory level of reported practices ( $\geq 35$ grades.) and for below $80 \%$ was considered unsatisfactory level of reported practices ( $<35$ grades.).

\section{Tool (III): Pediatric Quality of Life Scale:}

This tool was developed by Varni et al., (2006), be adapted and translated by the researcher into an Arabic language. It was formed of 23 items that are designed to measure the core dimensions of the health as delineated by WHO. Sickle Cell Anemia Module (adolescents from 12-18 years) was used to assess QOL for adolescents with sickle cell disease. Its' domains evaluated problems such as physical capacity (8 items), emotional (5 items) and social aspects (5 items) and school activities (5 items).

\section{The QOL scoring system:}

The items were rated on a 5-point Likerttype scale from "Never" to "Almost always". These items were scored as Never $=0$, Almost Never $=1$, Sometimes $=2$, Often=3, Almost always $=4$. Likert response scale items are reverse-scored and linearly transformed to a 0 100 scale $(0=100,1=75,2=50,3=25,4=0)$, so 


\section{Effect of Self-Learning Guidelines on Quality of Life and Self -Care Reported Practice of Adolescents with Sickle Cell Anemia}

that the higher Peds QL ${ }^{\mathrm{TM}}$ scores indicate better QoL.

Quality of life for adolescents with sickle cell disease was classified according to their response into good $(\geq 75 \%)$, average $(50<75 \%)$ and poor $(<50 \%)$.

\section{Validity and reliability of the study tools:}

The study tools were revised by a panel of three experts in the field of pediatric nursing to assess the validity of the study tools. Accordingly, minor modification was done in the form of rephrasing, organization, omission and addition of some questions. The reliability coefficient for the study tool was calculated using the correlation coefficient Cronbach's alpha test as:

\begin{tabular}{|c|c|c|}
\hline Tool & $\begin{array}{c}\text { No of } \\
\text { questio } \\
\text { ns }\end{array}$ & $\begin{array}{l}\text { Cronbac } \\
\text { h's Alpha }\end{array}$ \\
\hline Knowledge & 11 & 0.92 \\
\hline $\begin{array}{l}\text { Self-reported } \\
\text { practices }\end{array}$ & 44 & 0.90 \\
\hline QOL & 23 & 0.95 \\
\hline
\end{tabular}

Ethical and legal consideration:

Ethical aspect was considered before starting the study the researcher explained the aim, nature and expected outcomes of the research to the adolescents before their inclusion. They were informed that the study is harmless. Also, maintain confidentiality and privacy was taken into consideration regarding data collection. Moreover, the adolescents have the right to withdraw from the participation at any time. An oral consent was obtained from each subject to participate in the study.

\section{Pilot study:}

A pilot study was carried out during April 2019 on $10 \%$ of the studied adolescents (5 adolescents) to evaluate the applicability of the study tools and estimate the proper time required for answering the data required. All participants in the pilot study were excluded from the sample

\section{Field Work:}

The actual filed work started from the beginning of June 2019 up to the end of February 2020, 6 months for data collection and 3 months for follow up. The rate of adolescents' admission to hospital increased during hot and cold weather because this weather is a precipitating factor for pain crisis. The researcher was available in the study settings three days weekly (Sunday, Tuesday and Thursday) at morning and afternoon shifts to collect the data by previous tools.

The researcher started the data collection by introducing herself to the adolescents and giving them an explanation about the aim of the research and its expected outcome. The content of self-learning guidelines was prepared in the light of the actual needs assessment of the studied adolescents.

\section{Self-learning guidelines:}

It was designed by the researcher under guidance of the supervisors according to the actual needs' assessment of the study subjects after reviewing the related literature.

The self-learning guidelines was carried out in six sessions, the time of each session was ranged from 30-60 minutes. The studied adolescents were (50) divided into small groups numbers each group ranged between (5-10) adolescents. The self-learning guidelines were implemented for each group (3 days / week).

Different teaching methods were used as lecture, group discussion and role-play. Evaluation of the knowledge, self- care 
reported practices and quality of life for the studied adolescents carried out using the same pretest format as a post and follow up test. The researcher motivated the studied adolescents by encouraging them with words and gave pencils and notebook as reward to gain their participation.

\section{Assessment phase:}

A pretest carried out by using the study tools to assess the adolescents' knowledge, self- care reported practices regarding to sickle cell anemia and quality of their lives. The average time needed for the completion of each tool was ranged between 20-30 minutes.

\section{Planning phase:}

This phase included analysis of the pretest findings and identification for the actual needs of the adolescents' knowledge, self- care reported practices regarding to sickle cell anemia. Accordingly, the self-learning guidelines were designed by the researcher using simple Arabic language and different illustrated pictures in order to facilitate adolescents' understanding.

\section{Implementation phase:}

General and specific objectives of selflearning guidelines were stated and implemented to satisfy the actual needs of the studied adolescents. The implementation phase was achieved through six sessions at period of three days/ week 2 sessions /day. The time of each session was ranged from 30-60 minutes at inpatient and outpatient of pediatric hematology departments at Benha University and Benha Specialized Pediatric Hospitals. Each session started by a summary of the previous session and objectives the new one. Take into consideration, the use of the Arabic language that suit the adolescents' educational level. During sessions, each adolescent has an opportunity to ask questions and share information with each other. Otherwise, the researcher answered any questions about the guidelines as needed. Motivation and enhancement during sessions were used to enhance sharing in this study. Lecture and group discussion were used as teaching methods, colored posters and handout were given to adolescents at the end of the session. Adolescents were evaluated through oral questions and take feedback about content of each session.

\section{Evaluation phase:}

Evaluation was carried out immediately after the implementation of self-learning guidelines by using the same pretest format as a posttest and follow up that was carried out after 3 months. Some data was obtained in follow up phase using phone calls with study subjects

\section{Statistical Design:}

The collected data were organized tabulated and analyzed by using electronic computer and statistical analysis was done by using Statistical Package for Social Sciences (SPSS, version 26). Personal characteristics of the studied adolescents were presented in term of number and percentage. Mean and stander deviation for quantitative variable. Chi-square test and paired t test was used to study the comparison between pre, post and follow up of self-learning guidelines.

Chi-square test was also used to study the relation between the personal characteristics and their knowledge, self-care reported practices and quality of their life. The correlation coefficient test was used to study the correlation between adolescents' total knowledge score, total self-care reported practices score and their total quality of life score. 


\section{Effect of Self-Learning Guidelines on Quality of Life and Self -Care Reported Practice of Adolescents with Sickle Cell Anemia}

\section{Results}

Table (1): As regards the personal characteristics of the studied adolescents this table shows that, more than three quarters of them $76 \%$ were ranged in their age between $12-<15$ years with $X \pm S D$ 14.04 1.152 and more than half of them $54 \%$ were males. In addition, more than half of the studied adolescents $54 \%$ were in primary school education, and less than half of them $46 \%$ were ranked as the first child in their family. This table illustrates that more than three quarters of them $76 \%$ were living in rural areas and less than two thirds $62 \%$ of the number of their family are three members.

Figure (1) shows that, more than two thirds of the studied adolescents $68 \%$ had poor knowledge score regarding to sickle cell anemia at pre of self-learning implementation while, more than two thirds of them $70 \%$ and $68 \%$ had good level of knowledge score at post and follow up respectively. There was a statistical significant difference between total knowledge of studied adolescents regarding to sickle cell anemia at post and follow up as compared to pre self-learning guidelines implementation $(\mathrm{p}=\leq 0.05)$.

Figure (2) illustrates that, the majority of the studied adolescents $80 \%$ had unsatisfactory level of total self-reported practices regarding to sickle cell anemia at pre self-learning guidelines implementation while, more than two thirds of them $70 \%$ \& $68 \%$ had satisfactory level of total self care reported practices regarding to sickle cell anemia at post and follow up respectively. While, there was a statistical significant difference observed between the studied adolescents' total selfreported practices regarding to sickle cell anemia at post and pre as compared to pre selflearning guidelines implementation $(\mathrm{p}=\leq 0.05)$.

Figure (3) shows that, almost three quarters of the studied adolescents $74 \%$ had poor total score quality of life at pre of selflearning guidelines implementation. While less than half of them $48 \%$ and $46 \%$ had good total score quality of life at post and follow up respectively. The table represents a statistical significant difference was observed between the total score quality of life for the studied adolescents regarding to sickle cell anemia at post and follow up compared to pre selflearning guidelines implementation $(\mathrm{p}=\leq 0.05)$.

Table (2) clarifies that, there were a highly statistical positive correlation between the studied adolescents' total knowledge regarding to sickle cell anemia implementation and their quality of life at pre, post and follow up of self-learning guidelines implementation $(\mathrm{p}=<0.001)$.

Table (3) clarifies that, there were a highly statistical positive correlation between the studied adolescents' total self-care reported practices regarding to sickle cell anemia implementation and their quality of life at pre, post and follow up of self-learning guidelines implementation $(\mathrm{p}=<0.001)$. 
Table (1): Distribution of the studied adolescents according to their personal characteristics $(\mathbf{n}=\mathbf{5 0})$.

\begin{tabular}{|c|c|c|}
\hline Characteristics & No & $\%$ \\
\hline \multicolumn{3}{|l|}{ Age (in years): } \\
\hline $12-$ & 38 & 76.0 \\
\hline $15-18$ & 12 & 24.0 \\
\hline \multicolumn{3}{|c|}{$X \pm$ SD $14.04 \pm 1.152$} \\
\hline \multicolumn{3}{|l|}{ Gender: } \\
\hline Male & 27 & 54.0 \\
\hline Female & 23 & 46.0 \\
\hline \multicolumn{3}{|l|}{ Level of education: } \\
\hline Illiterate & 2 & 4.0 \\
\hline Read and write & 11 & 22.0 \\
\hline Primary education & 27 & 54.0 \\
\hline Preparatory education & 7 & 14.0 \\
\hline Secondary education & 3 & 6.0 \\
\hline \multicolumn{3}{|l|}{ Ranking of the child: } \\
\hline First & 23 & 46.0 \\
\hline Second & 12 & 24.0 \\
\hline Third & 9 & 18.0 \\
\hline Fourth & 6 & 12.0 \\
\hline \multicolumn{3}{|l|}{ Residence: } \\
\hline Urban & 12 & 24.0 \\
\hline Rural & 38 & 76.0 \\
\hline \multicolumn{3}{|c|}{ Number of family members: } \\
\hline 3 & 31 & 62.0 \\
\hline $4-5$ & 5 & 10.0 \\
\hline $5>$ & 14 & 28.0 \\
\hline
\end{tabular}


Effect of Self-Learning Guidelines on Quality of Life and Self -Care Reported Practice of Adolescents with Sickle Cell Anemia

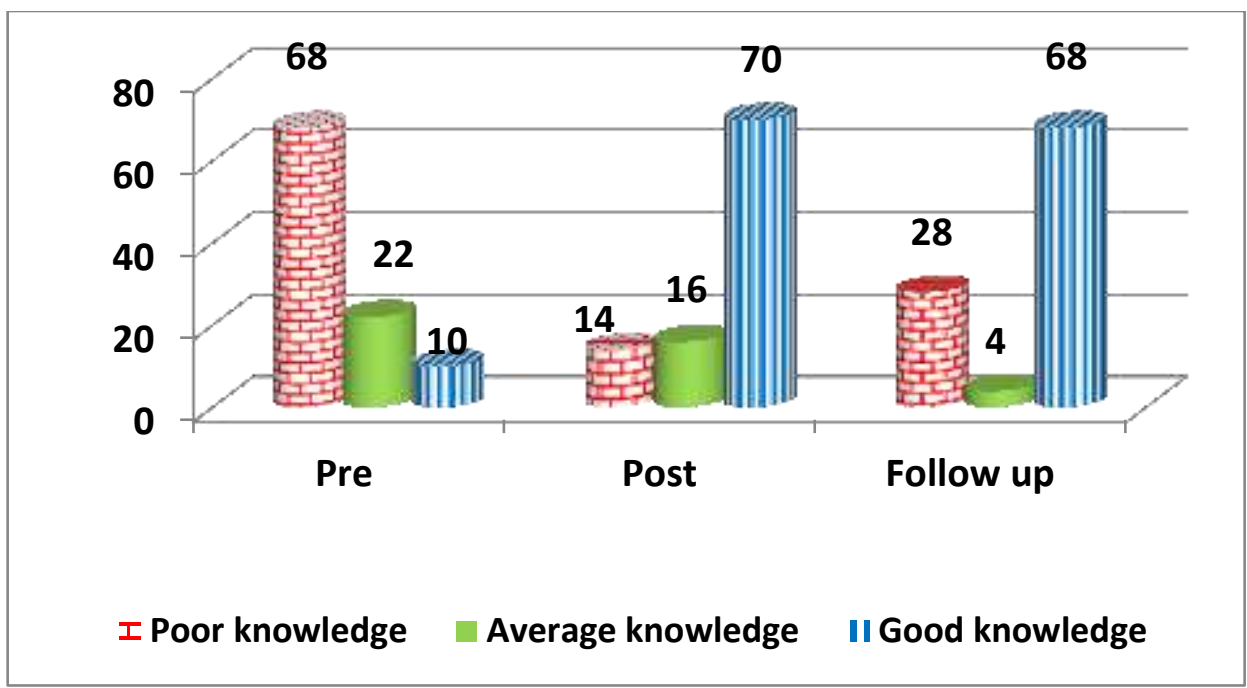

A statistical significant difference $\left(\mathrm{p} \leq 0.05^{*}\right) \quad x^{2}(1)=$ Relation between pre $\&$ post guidelines $(10.048)$ $x^{2}(2)=$ Relation between pre $\&$ follow-up guidelines (9.932)

Figure (1): Distribution of the studied adolescents' total knowledge score regarding to sickle cell anemia at pre, post and follow up of self-learning guidelines implementation $(n=50)$.

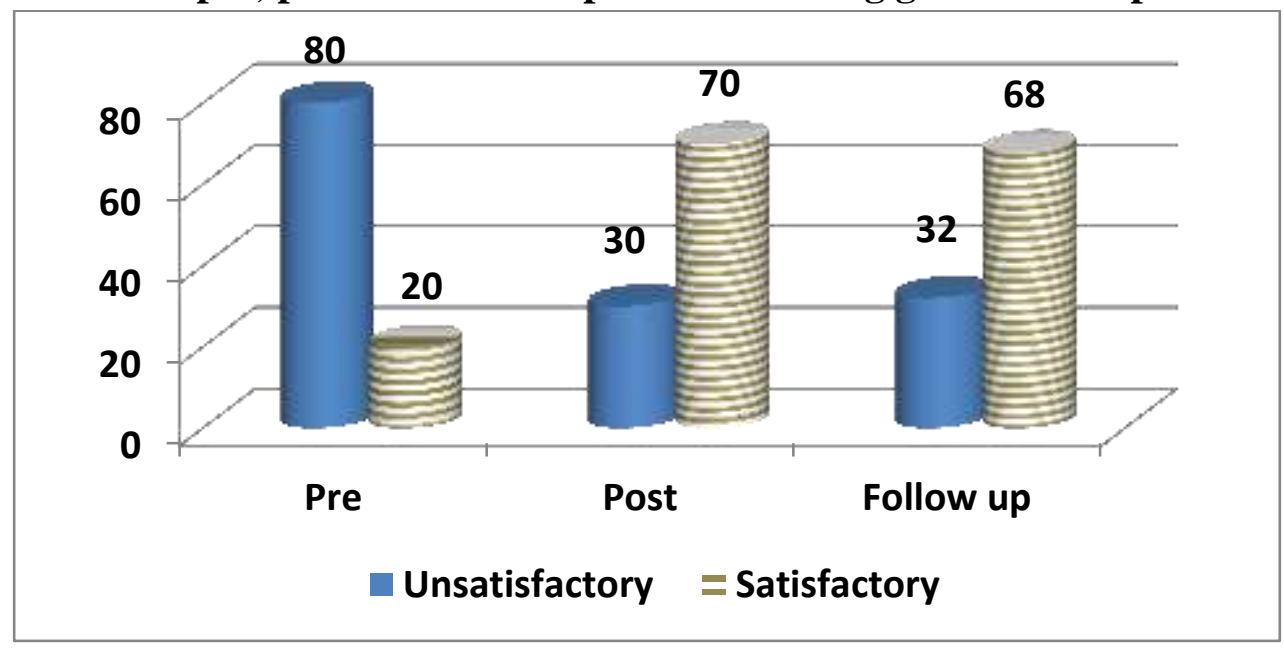

A statistical significant difference $(p \leq 0.05 *$

$x^{2}(1)=$ Relation between pre $\&$ post guidelines $(5.357)$

$x^{2}(2)=$ Relation between pre $\&$ follow-up guidelines (5.882)

Figure (2): Distribution of the studied adolescents' total score of self-care reported practices regarding to sickle cell anemia at pre, post and follow up of self-learning guidelines implementation $(\mathbf{n}=50)$. 


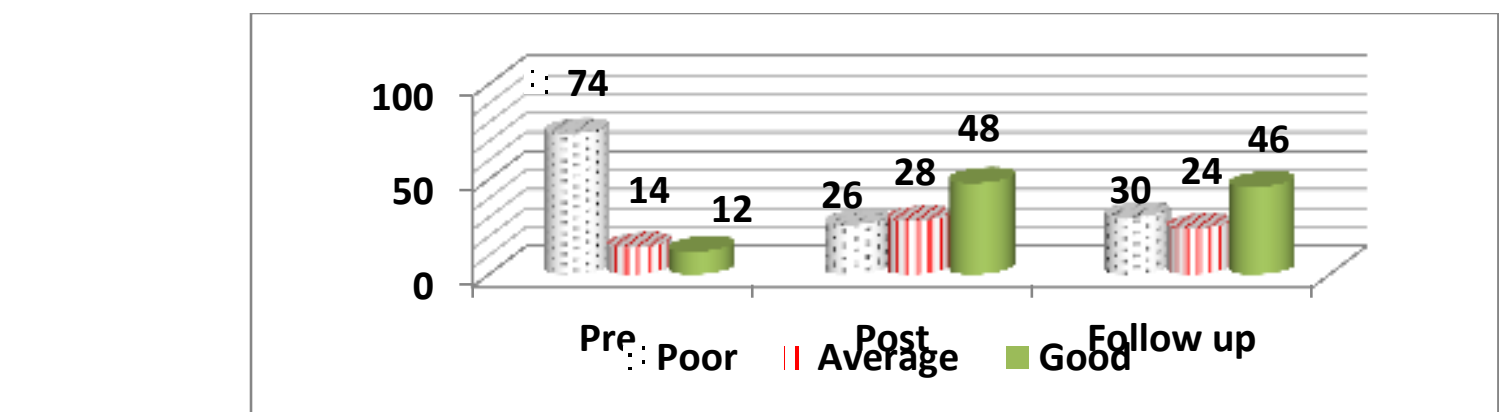

A statistical significant difference $(\mathrm{p} \leq \mathbf{0 . 0 5 *})$

$x^{2}(1)=$ Relation between pre $\&$ post guidelines $(15.723)$

$x^{2}(2)=$ Relation between pre $\&$ follow-up guidelines $(15.825)$

Figure (3): Distribution of the studied adolescents' quality of life total score regarding to sickle cell anemia at pre, post and follow up of self-learning guidelines implementation $(\mathbf{n}=\mathbf{5 0})$.

Table (2): Correlation between the studied adolescents' total level of knowledge regarding to sickle cell anemia and their quality of life at pre, post and follow up of selflearning guidelines implementation $(n=50)$.

\begin{tabular}{||l|c|c|c|c|c|c||}
\hline \multirow{3}{*}{ Total knowledge score } & \multicolumn{6}{c|}{ Total quality of life score } \\
\cline { 2 - 7 } & \multicolumn{2}{|c|}{ Pre } & \multicolumn{2}{c||}{ Post } & \multicolumn{2}{c||}{ Follow up } \\
\cline { 2 - 7 } & $\mathbf{R}$ & $\mathbf{P}$ & $\mathbf{r}$ & $\mathbf{P}$ & $\mathbf{R}$ & \multicolumn{1}{|c||}{$\mathbf{P}$} \\
\hline \hline Pre & 0.872 & $0.000^{* *}$ & 0.430 & $0.002^{* *}$ & 0.443 & $0.001^{* *}$ \\
\hline Post & 0.334 & $0.018^{*}$ & 0.782 & $0.000^{* *}$ & 0.757 & $0.000^{* *}$ \\
\hline Follow & 0.370 & $0.008^{* *}$ & 0.813 & $0.000^{* *}$ & 0.804 & $0.000^{* *}$ \\
\hline
\end{tabular}

A statistical significant difference $\left(p \leq 0.05^{*}\right)$

A highly statistical significant difference $(\mathrm{p} \leq 0.001 * *)$

r- Pearson Correlation Coefficient

Table (3): Correlation between the studied adolescents' total level of self care reported practices regarding to sickle cell anemia and their quality of life $s$ at pre, post and follow up of self-learning guidelines implementation $(n=50)$.

\begin{tabular}{|c|c|c|c|c|c|c|}
\hline \multirow{3}{*}{$\begin{array}{c}\text { Total self -care reported } \\
\text { practices }\end{array}$} & \multicolumn{6}{|c|}{ Total quality of life score } \\
\hline & \multicolumn{2}{|c|}{ Pre } & \multicolumn{2}{|c|}{ Post } & \multicolumn{2}{|c|}{ Follow up } \\
\hline & $\mathbf{R}$ & $\mathbf{P}$ & $\mathbf{r}$ & $\mathbf{P}$ & $\mathbf{R}$ & $\mathbf{P}$ \\
\hline Pre & 0.375 & $0.002 * *$ & 0.436 & $0.002 * *$ & 0.302 & $0.031 * *$ \\
\hline Post & 0.343 & $0.015 *$ & 0.654 & $0.001 * *$ & 0.654 & $0.000 * *$ \\
\hline Follow & 0.378 & $0.001 * *$ & 0.651 & $0.001 * *$ & 0.574 & $0.000 * *$ \\
\hline
\end{tabular}

A statistical significant difference $\left(\mathrm{p} \leq 0.05^{*}\right)$ A highly statistical significant difference $(\mathbf{p} \leq \mathbf{0 . 0 0 1} * *)$ r- Pearson Correlation Coefficient 


\section{Effect of Self-Learning Guidelines on Quality of Life and Self -Care Reported Practice of Adolescents with Sickle Cell Anemia}

\section{Discussion}

Sickle Cell Anemia (SCA) is a genetic disorder of hemoglobin that affects millions worldwide. Complications of the disease can be severe and life threatening causing repeated referrals to the emergency department or hospital to receive medical care that lead to lower self-esteem, feelings of frustration, depression, anxiety, stress and poor quality of life. Therefore, selflearning guidelines provide adolescents with SCA with necessary information, skills and motivation to improve quality of life (Abd Elmoneim et al., 2019).

In relation to personal characteristics of the studied adolescents, more than three quarters of them were ranged between $12-<15$ years $X \pm S D$ age $(14.04 \pm 1.152$. This finding agreed with the study of Kambasu, et al., (2019) entitled "Health-Related Quality of Life of Adolescents with Sickle Cell Disease in SubSaharan Africa" who mentioned that, more than three quarters of the studied adolescents were between the age of $12-15$ years $\mathrm{X} \pm \mathrm{SD} 14.25$ years.

Regarding the gender of the studied adolescents, in this study it was found that, more than half of them were males. This finding was in the same line with Stephen, et al., (2018) in the study entitled "Prevalence of Sickle Cell Disease among Children Attending Plateau Specialist Hospital" who informed that, SCD affects males and females equally because the inheritance is autosomal recessive.

According to the study of Salih, (2019) entitled "The Impact of Sickle Cell Anemia on The Quality of Life of Sticklers at School Age" who reported that, more than half of the children was male. The researcher could explain this result as, the SCA occurs in children of carrier parents in the same proportion across gender in a ratio of 1:1 between male and female.

More than half of the studied adolescents were in primary school education. This finding was in agree with a study carried out by Adgoke, et al., (2015) about "Sickle Cell Disease Clinical Phenotypes in Children from South Western Nigeria" who found that, nearly half of children at primary school level. The adolescent still in primary school despite their age, this may be related to the recurrent pain crisis require frequent hospitalization and frequent absenteeism from the school. In addition, adolescent with SCA may have short attention span that may leads to, learning difficulties.

Concerning the total knowledge of the studied adolescents regarding SCA the current study illustrated that, more than two thirds of the studied adolescents had poor knowledge score regarding to sickle cell anemia at pre of self-learning implementation. This finding was compatible with the study of Boadu \& Addoah, (2018) entitled "Knowledge, Beliefs and Attitude towards Sickle Cell Disease among University Students" who illustrated that, nearly two thirds of the participants had poor knowledge about sickle cell disease. This might be due to that the participants in the present study didn't engage in any health educational program.

The study also, supported by Asnani, et al., (2016) who conducted a study entitled "Interventions for and Caregivers to Improve Knowledge of Sickle Cell Disease and Recognition of Its Related Complications" and stated that, educational programs improved patient' (aged 15 -18 years) knowledge about SCD. This may be related to lack of knowledge 
about sickle cell anemia that fulfilled after the study implementation.

Concerning the total score of self-care reported practices of the studied adolescents about sickle cell anemia the current study revealed that, there was an improvement in selfcare reported practices about SCA at post and follow up as compared to pre self-learning guidelines implementation. These findings were similar to the study of Matthie \& Jenerette, (2017) entitled "Understanding the SelfManagement Practices of Young Adults with Sickle Cell Disease" who reported that, study participants indicated a desire to engage in selfmanagement to optimize health and reduce incidence of pain crisis.

The present study findings were agreed with the study conducted by Beverung, et al., (2015) entitled "Health-Related Quality of Life in Children with Sickle Cell Anemia: Impact of Blood Transfusion Therapy" which pointed out that, regular blood transfusion and follow up was found to improve health among children with SCD. This could be attributed to the fact that, adolescents with SCA delay care-seeking because of competing time demands related to family, school, and work so regular self-care guidelines implementation may be effective in helpful in managing pain through staying hydrated and taking medications.

Additionally, the study of the same researcher was found that, significant differences in the change in HRQL were detected between study groups from baseline to exit in one area. Change in health over time for the transfusion group was significantly greater than the increase in change in health over time for the observation group. This may be emphasized the importance of self-learning guidelines for the children with SCA.

Regarding to total quality of life score for the studied adolescents with SCA, in the present study found that, there was a statistical significant difference was observed between the total score quality of life for the studied adolescents regarding to sickle cell anemia at post and follow up compared to pre selflearning guidelines implementation. These findings were in an accordance with a study carried out by Badawy, et al., (2017) entitled as "Barriers to Hydroxyurea Adherence and Health-Related Quality of Life in Adolescents and Young Adults with Sickle Cell Disease" it was mentioned that, children had better HRQoL because of the impact of a disease modifying therapy and regular follow up.

These findings was almost similar to the study by Ahmadi, et al., (2015) entitled "The Effectiveness of Self-Management Program on Quality of Life in Patients with Sickle Cell Disease" who mentioned that, all dimensions of QoL score after intervention were significantly increased compared to those before the intervention. Repeated measures test showed that the mean score of all QoL dimensions and the total QoL score decreased in the thirty-sixth week, compared to twelfth week. However, it was significantly enhanced in comparison with the intervention baseline. This may be due to children with SCA need continuous learning guidelines to improve their quality of life.

The present study findings were consistent with Pandarakutty, et al., (2019) who conducted a study entitled "Effectiveness of Nurse Led Intervention on Health Related Quality of Life among Children with Sickle Cell Disease in Oman: A Pilot 


\section{Effect of Self-Learning Guidelines on Quality of Life and Self-Care Reported Practice of Adolescents with Sickle Cell Anemia}

Study" and illustrated that, the participants in study group had poor HRQOL scores in pretest. After nurse led intervention, the HRQOL score in the study group significantly improved.

Similarly, according to Al-Azri, et al., (2016) who conducted a study which entitled" Knowledge and Health Beliefs Regarding Sickle Cell Disease among Omanis in A Primary Healthcare Setting" and mentioned that, the quality of life among children with SCD remains poor mainly due to lack of awareness about the disease. Therefore, health promotion and educational program are needed in order to increase the public awareness on SCA to promote quality of life.

Regarding the correlation between the studied adolescents' total knowledge and total self-care reported practices score regarding to sickle cell anemia and their quality of life there were a highly statistical positive correlation among total knowledge and total self-care reported practices score with their quality of life at pre, post and follow up of self-learning guidelines implementation.

These findings were in an agreement with Asnani, et al., (2017) in the study entitle "Disease Knowledge, Illness Perceptions, and Quality of Life in Adolescents with Sickle Cell Disease: Is There a Link?" Who hypothesized that, higher disease knowledge, and positive illness perceptions about self-care practice were positively associated with QoL. This attributes that the importance of good knowledge and self-care practices for adolescents with SCA in improving their quality of life

\section{Conclusion:}

Self-learning guidelines implementation was effective in improving the QoL of adolescents with SCA through improving their knowledge and self-care reported practices.

\section{Recommendations}

- In service training program for adolescent with the sickle cell anemia to enhance their quality of life.

- Conducting premarital screening programs for raising awareness of children and adolescents regarding the nature hereditary of SCA\& associated complication.

- Providing psychological support and increase the link between adolescents and their family, school officials and health workers could help in alleviating difficulties especially academic performance.

- Continuous monitoring and evaluating self-care practices for children with sickle cell disease for early detection and solving any problem.

- Emphasizing on the role of nurses as health educator for adolescents with sickle cell anemia.

\section{References}

Abd Elmoneim, A., Al Hawsawi, Z., Badr, Z., Mahmoud, B., A., Abdulmalik, A., Almulla, A., Sonbol, A. and Makhdoum, A. (2019). Causes of Hospitalization in Sickle cell Disease Children in Western Region of Saudi Arabia. Saudi Medical Journal, 40(4): 401-404. doi: 10.15537/smj.2019.4.24049

Adegoke, S.A., Adeodu, O.O. and Adekile, A.D. (2015). Sickle cell disease clinical phenotypes in children from South-Western, Nigeria. Nigerian Journal of Clinical Practice, 18(1):95-101. Available at https://www.njcponline.com/text.asp?2015/ 18/1/95/146987 
Ahmadi, M., Jahani, S., Poormansouri, S., Shariati, A., and Tabesh, H. (2015). The Effectiveness of Self-management Program on Quality of Life in Patients with Sickle Cell Disease. Iranian Journal of Pediatric Hematology and Oncology, 5(1): 18-26.

Al-Azri, M., Al-Belushi,R., Al-Mamari, M., Davidson, R. and Mathew, A. (2016). Knowledge and Health Beliefs Regarding Sickle Cell Disease among Omanis in A primary Healthcare Setting, Sultan Qaboos University. Medical Journal, 16(4): e437e444. doi 10.18295/squmj.2016.16.04.006.

Asnani M., Quimby, K., Bennett, N. and Damian K. Francis, D. (2016). Interventions for patients and caregivers to improve knowledge of sickle cell disease and recognition of its related complications. Cochrane Database of Systematic Reviews Journal, (10): 12-15. doi: 10.1002/14651858.CD011175.

Asnani, M., Barton-Gooden, A., Grindley, M. and Knight-Madden, J. (2017). Disease Knowledge, Illness Perceptions, and Quality of Life in Adolescents with Sickle Cell Disease: Is There a Link? Global Pediatric Health Journal, 4(1): 1-10. Available at https://doi.org/10.1177/2333794X17739194 2019/3/27.

Badawy, S., Thompson, A., Penedo, F., Lai, J., Rychlik, K. and Liem, R. (2017). Barriers to Hydroxyurea Adherence and HealthRelated Quality of Life in Adolescents and Young Adults with Sickle Cell Disease. European Journal of Haematology, 98 (6): 608-614. doi: 10.1111/ejh.128782019/12/2
Beverung, L.M., Strouse, J.J., Hulbert, M.L., Neville, K., Liem, R.I., Inusa, B., Fuh, B., King, A., Meier, E.R., Casella, J., MR, D.B. and Panepinto, J.A.(2015). Health-Related Quality of Life in Children with Sickle Cell Anemia: Impact Of Blood Transfusion Therapy. American Journal of Hematology, 90 (2):139-43. Available at https://doi 10.1002/ajh.23877.

Boadu, I. and Addoah, T. (2018). Knowledge, Beliefs and Attitude towards Sickle Cell Disease among University Students. Journal of Community Medicine and Health Education, 8(1):593. DOI: 10.4172/2161-0711.1000593.

Downes, M., Kirkham, F., Berg, C., Telfer, P. and De Haan, M. (2019). Executive Performance on the Preschool Executive Task Assessment in Children with Sickle Cell Anemia and Matched Controls. ChildNeuropsychology

Journal, 25(1): 278-285. Available at https://doi.org/10.1080/09297049.2018.14919 62

Druye, A., Robinson, B. and Nelson $K$. (2018). Self-Management Recommendations for Sickle Cell Disease: A Ghanaian Health Professionals' Perspective. Health Science Reports Journal, 1 (11): e88. doi: 10.1002/hsr2.88

Hilker, K., Jordan, S., Jensen, S. and Elkin, T. (2006). Development of a Screening Instrument of Adherence in Pediatric Sickle Cell Disease. Children's Health care Journal, 35(3), 235-246. doi: 10.1207/s15326888chc3503_3 
Jain, S.H., Bakshi, N. and Krishnamurti, L. (2018). Acute Chest Syndrome in Children with Sickle Cell Disease. Pediatric Allergy, Immunology, and Pulmonology Journal, 30 (4):191-201. doi: 10.1089/ped.2017.0814

Kambasu, D., Rujumba, J., Lekuya, H., Munube, D. and Mupere, E. (2019). HealthRelated Quality of Life of Adolescents with Sickle Cell Disease in Sub-Saharan Africa: A Cross-Sectional Study. BMC Hematology, 19(1):2-9. Available at https://doi.org/10.1186/s12878-019-0141-8

Lim, S., Karlson, C., Edmond, N., Welkom, S., Osunkwo, I. and Cohen, L. (2019). Emotion-Focused Avoidance Coping Mediates the Association between Pain and Health-Related Quality of Life in Children With Sickle Cell Disease. Journal of Pediatric Hematology and Oncology, 41(3): 194-201. doi: $10.1097 / \mathrm{mph} .0000000000001429$

Lori, C., Walton, A., Shook, M., Lisa, M.,Ware, O., Russell E., Treadwell, M., Kay, L., Peugh, J., McTate, E., Oyeku, S., Nwankwo, C., Brinkman, B. and William, B. (2019). Development of A Hydroxyurea Decision Aid for Parents of Children with Sickle Cell Anemia. Journal of Pediatric Hematology and Oncology, 41(1): 56-63. doi: 10.1097/MPH.0000000000001257

Matthie, N. and Jenerette, C. (2017). Understanding the Self-Management Practices of Young Adults with Sickle Cell Disease.
Journal of Sick Cell Disease Hemoglobinopathies, 2017(1): 76-87.

Pandarakutty, S., Murali, K., Arulappan, J. and Deepa Shaji Thomas, S.H. (2019). Effectiveness of Nurse Led Intervention on Health Related Quality of Life among Children with Sickle Cell Disease in Oman. Advances in Hematology Journal, 2019(1): 9. https://doi.org/10.1155/2019/6045214

Salih, K. (2019). The Impact of Sickle Cell Anemia on the Quality of Life of Sicklers at School Age. Journal of Family Medicine and Primary Care, 8(2):468471. doi: 10.4103/jfmpc.jfmpc_444_18

Stephen, N., Nden, N., Gusen, N., Kumzhi, P., Gaknung, B., Auta, D., Bulndi, L., Mbursa, C., Kumari, V. and Nanvyat, N. (2018). Prevalence of Sickle Cell Disease among Children Attending Plateau Specialist Hospital, Jos, Nigeria. Acta Medica International Journal, 5(1): 20-3. doi: 10.4103/ami.ami_60_17

Varni, J., Seid, M. and Rode, C. (2006). The Peds QL: Measurement Model for The Pediatric Quality Of Life Inventory. Medical Care Journal, 37(1):126-139. doi: 10.1097/00005650-199902000-00003. 
تأثير إرشادات التعلم الأتي علي جودة حياة المراهقين المصابين بأنيميا الخلايا المنجلية نورا مهاي فوده- رندا محم عدلي- فاتن شفيق محمود- راويه عبدالغنى محمل

يعد مرض أنيميا الخلايا المنجلية مرض مزمن يرتبط بالعديد من المشاكل الجسدية و النفسية والاجتماعية التي يمكن أن تؤثر على جودة الحياة. لذلك فإن إرشادات التعلم الذاتي لها تأثثر كبير في تحسين جودة الحياة والحالة الصحية للطفل المراهق. لذلك هدفت هذه الدراسة إلى تقييم تأثير إرشادات التعلم الذاتي على جودة حياة المر اهقين المصابين بأنيميا الخلايا المنجلية. وقد أجريت الدراسة قسم أمراض الدم والعيادات الخارجية في مستشفي جامعة بنها ومستشفى بنها التخصصي للأطفال علي •0 طفل مراهق من المصابين بأنيميا الخلايا المنجلية. حيث كثفت النتائج عن أن مرض أنيميا الخلايا المنجلية يؤثر علي جودة حياة الأطفال المر اهقين. حيث كانت إرشادات التعلم الذاتي فعالة في تحسين معلومات الأطفال المراهقين عن مرض أنيميا الخلايا المنجلية، وممارسات الرعاية الذاتية المبلغة وجودة حياتهم. كما أوصت الدر اسة بأهمية إجراء برنامج لتدريب المر اهقين المصابين بأنيميا الخلايا المنجلية لتحسين جودة حياتهم.. 